intussusception in the descending aorta. He had complained of vague abdominal pain, which was caused by dynamic obstruction of the visceral arteries, as evidenced by abatement of these symptoms after surgery.

The possibility of visceral malperfusion was diagnosed preoperatively, using computed tomography images. However, these images failed to definitively demonstrate the objective findings of visceral malperfusion, which would have been shown by abdominal echograms or dynamic magnetic resonance images. This case report brings the added insight that the very rare complication of intimo-intimal intussusception in type B aortic dissection may cause visceral malperfusion syndrome.

\section{Reference}

1. Kim SY, Hwang HY, Lee W, Ahn H. Aortic intimointimal intussusception in chronic type B dissection causing dynamic obstruction of visceral arteries. J Thorac Cardiovasc Surg. 2015;150:e33-5.

\title{
Intraoperative vacuum-assisted closure following in situ graft replacement for an infected thoracic aortic graft
}

Katsuhiro Hosoyama, MD, Shunsuke Kawamoto, MD, PhD, Naotaka Motoyoshi, MD, PhD, and Yoshikatsu Saiki, MD, PhD, Sendai, Japan

From the Division of Cardiovascular Surgery, Tohoku University Graduate School of Medicine, Sendai, Japan.

Disclosures: Authors have nothing to disclose with regard to commercial support.

Received for publication May 13, 2015; accepted for publication May 26, 2015; available ahead of print July 2, 2015.

Address for reprints: Yoshikatsu Saiki, MD, PhD, Division of Cardiovascular Surgery, Tohoku University Graduate School of Medicine, 1-1 Seiryocho, Aoba-ku, Sendai, Japan (E-mail: yoshisaiki@med.tohoku.ac.jp).

J Thorac Cardiovasc Surg 2015;150:e36-8 $0022-5223 / \$ 36.00$

Copyright $\subset 2015$ by The American Association for Thoracic Surgery http://dx.doi.org/10.1016/j.jtcvs.2015.05.061

See related commentary on pages e39-40.

Prosthetic graft infection after surgery to reconstruct the thoracic aorta is a devastating complication, and the management remains a challenge for surgeons. ${ }^{1}$ In particular, patients at high risk with anastomotic lesions such as false aneurysms, septic emboli, or ruptured suture lines, which require emergency in situ replacement, are associated

TABLE 1. Patient summary

\begin{tabular}{|c|c|c|c|c|c|c|c|c|c|c|c|c|}
\hline Case & Age (y) & Sex & Risk factor & Primary surgery & $\begin{array}{c}\text { Clinical } \\
\text { presentation } \\
\text { before second } \\
\text { surgery }\end{array}$ & $\begin{array}{l}\text { Duration } \\
\text { from } \\
\text { previous } \\
\text { surgery }\end{array}$ & Pathogen & $\begin{array}{l}\text { Operative } \\
\text { procedure }\end{array}$ & $\begin{array}{l}\text { Bleeding } \\
\text { in postop } \\
24 \mathrm{~h}(\mathrm{~mL})\end{array}$ & $\begin{array}{c}\text { Period } \\
\text { of VAC } \\
\text { therapy (d) }\end{array}$ & $\begin{array}{c}\text { Follow-up } \\
\text { duration (y) }\end{array}$ & $\begin{array}{c}\text { Recurrent } \\
\text { infection }\end{array}$ \\
\hline 1 & 54 & M & $\begin{array}{l}\text { Diabetes } \\
\text { mellitus }\end{array}$ & ATA replacement & $\begin{array}{l}\text { False } \\
\text { aneurysm }\end{array}$ & $2 \mathrm{mo}$ & $\begin{array}{l}\text { Streptococcus } \\
\text { species }\end{array}$ & $\begin{array}{l}\text { TAR with } \\
\text { allograft and } \\
\text { prosthetic } \\
\text { graft }\end{array}$ & 650 & 9 & 5.7 & None \\
\hline 2 & 73 & M & None & CCA replacement & $\begin{array}{l}\text { False } \\
\text { aneurysm } \\
\text { adjacent to } \\
\text { aortic arch }\end{array}$ & $5 \mathrm{~d}$ & Unspecified & $\begin{array}{l}\text { TAR with } \\
\text { prosthetic } \\
\text { graft }\end{array}$ & 660 & 9 & 2.2 & None \\
\hline 3 & 75 & $\mathrm{~F}$ & None & ATA replacement & $\begin{array}{l}\text { Bacterial } \\
\text { vegetation }\end{array}$ & $15 \mathrm{mo}$ & Candida albicans & $\begin{array}{l}\text { ARR with } \\
\text { xenograft } \\
\text { valve and } \\
\text { prosthetic } \\
\text { graft }\end{array}$ & 640 & 9 & 1.9 & None \\
\hline 4 & 67 & M & Steroid use & ATA replacement & False aneurysm & $16 \mathrm{mo}$ & $\begin{array}{l}\text { Propionibacterium } \\
\quad \text { acne }\end{array}$ & $\begin{array}{l}\text { AAR with } \\
\text { prosthetic } \\
\text { graft }\end{array}$ & 740 & 9 & 1 & None \\
\hline
\end{tabular}

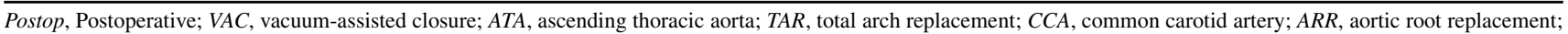
$A A R$, ascending aorta replacement. 



FIGURE 1. Preoperative computed tomographic images of the 4 patients. A, Patient 1 had a false aneurysm contiguous with the ascending aorta and a perigraft abscess. B, Patient 2 had a false aneurysm contiguous with the left common carotid artery. C, Patient 3 had a mobile vegetation at the ascending aortic graft. D, Patient 4 had a false aneurysm contiguous with the ascending aorta and a perigraft abscess.

with a high probability of poor outcome. In these situations, in addition to the serious nature of the preoperative condition, there is considerable risk of recurrent infection of the replaced graft.

The vacuum-assisted closure (VAC) system is a noninvasive treatment device used for pressure ulcers and other chronic wounds and is currently a treatment of choice for poststernotomy mediastinitis in many institutions.,3 The installation of a VAC system immediately after replacement of infected grafts with cardiopulmonary bypass has not been conclusively validated, however, because of concerns about increased blood loss or suture line rupture. This report describes consecutive 4 cases in which intraoperative installation of a VAC system was performed, followed by delayed sternal closure (DSC), for thoracic aortic graft infection requiring prompt in situ replacement. To the best of our knowledge, no previous reports of this technique have been published.

\section{CLINICAL SUMMARY}

The patient summary is shown in Table 1 and Figure 1. In all cases, after patients came to our department, emergency in situ aortic graft replacement was performed uneventfully, and then the VAC system was installed intraoperatively as previously described. ${ }^{2,3}$ In brief, after $0.01 \%$ gentian violet solution was applied around the prosthetic graft, polyurethane foam (Hydrosite; Smith \& Nephew Inc, Fla) was packed around the graft, and the front was also covered with polyurethane foam. Then a noncollapsible chest tube was placed in the middle of the incision, and the incision perimeter 
was covered with lap sponges (Kawamoto Co Ltd, Osaka, Japan). Finally, the wound was covered with a $3 \mathrm{M}$ Ioban 2 antimicrobial surgical incise drape (3M Health Care Inc, St. Paul, Minn) and vacuumed at $-99 \mathrm{~cm} \mathrm{H}_{2} \mathrm{O}$ with a vacuum pump (HAMA Servo drain; Hama Medical Industrial Co Ltd, Tokyo, Japan). The irrigation and packing procedure was repeated daily with the patient under sedation. The mean volume of blood drained under the VAC system in the first $24 \mathrm{~h}$ was $672.5 \pm 48.1 \mathrm{~mL}$, which was not excessive relative to that after other cardiac operations. There were no adverse events related to VAC therapy, such as anastomotic rupture or bleeding. In all patients, VAC therapy was continued for 9 days, after which DSC was performed. Only in patient 1 was omental wrapping not performed, because of previous use of the omentum. There were no in-hospital deaths. One patient had a cerebral infarction in the left hemisphere, with associated right hemiparesis, but no other postoperative complications occurred. The median follow-up duration was 2.1 years (range, 1.2-4.8 years), and at the time of writing all patients were in stable condition with no recurrence of infection.

\section{DISCUSSION}

As shown in these 4 cases, the use of VAC and DSC could decrease the risk of recurrent infection. Removal of exudate from the mediastinal and perigraft cavities can facilitate successful management of the infection..$^{2-4}$ The enhanced neovascularization induced by the negative pressure during VAC therapy can also aid in recovery. ${ }^{4,5}$ In addition, in our patient cohort the negative pressure of the VAC system, which is much higher than that of a conventional drain, caused no adverse events such as anastomotic rupture or increase in bleeding, despite the fact that VAC was applied immediately after cardiopulmonary bypass with hypothermia (in an unsettled coagulation state). To our understanding, the negative pressure is distributed equally to the entire mediastinal surface with VAC therapy. The risk of tissue injury as a result of unevenly distributed negative pressure can be diminished. Furthermore, at the anastomotic site, the negative force is supposedly directed equally to both sides of the suture line, so disruption of the anastomoses is unlikely.

In this series, we used DSC exclusively after ensuring negative mediastinal tissue cultures multiple times. Because the prosthetic grafts used for in situ replacement are subject to recurrent infection when introduced into the previously active infectious field, we consider it appropriate to delay chest closure until microbial cultures become negative.

In conclusion, our method of in situ graft replacement with intraoperative installation of a VAC system followed by DSC may be a safe therapeutic option for thoracic aortic graft infection and may be highly effective in long-term prevention of recurrent graft infection.

\section{References}

1. Coselli JS, Köksoy C, LeMaire SA. Management of thoracic aortic graft infections. Ann Thorac Surg. 1999;67:1990-3; discussion 1997-8.

2. Saiki Y, Kawamoto S, Sai S, Tabayashi K. An effective vacuum-assisted closure treatment for mediastinitis with aortic arch replacement. Interact Cardiovasc Thorac Surg. 2008;7:712-4.

3. Suzuki T, Kawamoto S, Motoyoshi N, Akiyama M, Kumagai K, Adachi O, et al. Contemporary outcome of the surgical management of prosthetic graft infection after a thoracic aortic replacement: is there a room to consider vacuum-assisted wound closure as an alternative? Gen Thorac Cardiovasc Surg. 2015;63:86-92.

4. Wackenfors A, Sjögren J, Gustafsson R, Algotsson L, Ingemansson R, Malmsjö M. Effects of vacuum-assisted closure therapy on inguinal wound edge microvascular blood flow. Wound Repair Regen. 2004;12:600-6.

5. Petzina R, Gustafsson L, Mokhtari A, Ingemansson R, Malmsjö M. Effect of vacuum-assisted closure on blood flow in the peristernal thoracic wall after internal mammary artery harvesting. Eur J Cardiothorac Surg. 2006;30:85-9. 